\title{
Loss of Plant Species Diversity Reduces Soil Erosion Resistance
}

\author{
Frank Berendse,${ }^{1 *}$ Jasper van Ruijven, ${ }^{1}$ Eelke Jongejans, ${ }^{2}$ and Saskia \\ Keesstra $^{3}$
}

\begin{abstract}
${ }^{1}$ Nature Conservation and Plant Ecology Group, Wageningen University, Droevendaalsesteeg 3a, 6708 PB Wageningen, The Netherlands; ${ }^{2}$ Animal Ecology and Ecophysiology Group, Radboud University Nijmegen, P.O. Box 9100, 6500 GL Nijmegen, The Netherlands; ${ }^{3}$ Soil Physics and Land Management Group, Wageningen University, Droevendaalsesteeg 4, 6708 PB Wageningen, The Netherlands
\end{abstract}

\begin{abstract}
In many estuarine areas around the world, the safety of human societies depends on the functioning of embankments (dikes) that provide protection against river floods and storm tides. Vegetation on land-side slopes protects these embankments from erosion by heavy rains or overtopping waves. We carried out a field experiment to investigate the effect of plant species diversity on soil loss through erosion on a simulated dike. The experiment included four diversity treatments $(1,2,4$, and 8 species). In the third year of the experiment, we measured net annual soil loss by measuring erosion losses every 2 weeks. We show that loss of plant species diversity reduces erosion resistance on these slopes: net annual soil loss increased twofold when diversity declines fourfold. The different plant species had strongly diverging effects on soil erosion, both in the single-species
\end{abstract}

\section{INTRODUCTION}

The Convention on Biological Diversity of Rio de Janeiro (1993) stressed the importance of biodiversity for ecosystem functions that are essential to mankind. Since then, many experiments have been performed to analyze the impacts of biodi-

Received 9 October 2014; accepted 22 February 2015; published online 31 March 2015

Author contributions $\mathrm{FB}$ and JvR conceived of and designed the study; FB, JvR, EJ, and SK analyzed the data; FB wrote the paper with inputs from JvR, EJ and SK.

*Corresponding author; e-mail: frank.berendse@wur.nl and in the multi-species plots. Analysis of the dynamics of the individual species revealed that the main mechanism explaining the strong effects of plant species diversity on soil erosion is the compensation or insurance effect, that is, the capacity of diverse communities to supply species to take over the functions of species that went extinct as a consequence of fluctuating environmental conditions. We conclude that the protection and restoration of diverse plant communities on embankments and other vegetated slopes are essential to minimize soil erosion, and can contribute to greater safety in the most densely populated areas of the world.

Key words: plant species diversity; soil erosion; plant competition; insurance effect; compensation effect. versity loss on plant production (Hector and others 1999; Tilman and others 2001; Van Ruijven and Berendse 2005), decomposition (Handa and others 2014), soil respiration (Dias and others 2010), invasion resistance (Van Ruijven and others 2003), and ecosystem stability (Gross and others 2014). Such ecosystem processes are crucial and determine-amongst others-the amount of herbivore biomass that can be sustained. However, these experiments did not yet address the impacts of diversity loss on ecosystem functions that have direct physical impacts on human societies (Cardinale 
and others 2012). Examples of such functions are production of clean drinking water, erosion resistance, and regulation of the temperature on the Earth's surface.

Soil erosion resistance is an important feature of undisturbed, non-fertilized ecosystems. In undisturbed forests, erosion losses are 70-2000 times lower than those from arable land and 20-100 times lower than losses from fertilized pastures (Cerdan and others 2010; Kateb and others 2013). It is important to answer the question of what the consequences of the worldwide losses of plant species diversity (Van Vuuren and others 2006) will be for the erosion resistance not only on man-made river and sea embankments, but also on sloping pastures that provide a significant part of food production in many parts of the world (Pimentel and others 1987).

Estuarine areas worldwide harbor extremely high population densities (with 22 of the world's 32 largest cities (Ross 1995)) and are at high risk of flooding events because they are below sea level or under the influence of rivers in which discharge regimes are changing due to global warming. One of the many examples is the Netherlands, where $26 \%$ of the land is below sea level and $29 \%$ is at risk of being inundated when the two main rivers are at peak discharge (Parry and others 2007; Netherlands Environmental Assessment Agency 2010). Only dikes and coastal dunes protect these parts of the country, where nearly 9 million people live and roughly $65 \%$ of the Dutch GNP is generated. On the basis of IPCC assessments (Parry and others 2007) of expected regional sea-level rise and increased maximum river discharge, independent reports have recommended that the present flood protection levels of all diked areas be improved by a factor of 10 and that the new standards be set as soon as possible (Delta Commissie 2008).

In many countries, sea or river side slopes of embankments are often protected by basalt blocks or other stony materials, but heavy rain and powerful overtopping waves may induce erosion of land-side slopes covered with grassland vegetation. Application of chemical fertilizers or abrupt changes in management from haymaking to grazing or vice versa often lead to dramatic losses of species diversity (Berendse and others 1992; Silvertown and others 2006; Pierik and others 2011) and to substantial changes in species composition (Elberse and others 1983), whereas the restoration of species diversity takes many years (Pierik and others 2011).

We hypothesized that diversity loss would result in increased soil losses through erosion. All field experiments so far have shown negative impacts of species loss on aboveground plant production (for example, Van Ruijven and Berendse 2005) and on root mass (Mommer and others 2010). Higher aboveground biomass reduces splash erosion (resulting from the kinetic energy of raindrops or waves), whereas increased root mass favors resistance to rill erosion (resulting from superficial downslope transport of soil particles) (Gyssels and others 2005; Durán Zuazo and Rodríguez Pleguezuolo 2008). A second possible mechanism that might contribute to the hypothesized relation between diversity and soil erosion is the reduced capacity of species-poor communities to provide species that can rapidly fill the gaps that other species leave behind when they go extinct as a consequence of changing environmental conditions. We performed a field experiment on a simulated dike to test our hypothesis and to investigate these two possible mechanisms behind the hypothesized negative impact of diversity loss on soil erosion.

\section{Materials AND Methods}

In March 2010, 98 plots on the slope of a low, simulated dike were planted with seedlings of four grass species (Agrostis capillaris, Anthoxanthum odoratum, Festuca rubra, and Holcus lanatus) and four dicot species (Centaurea jacea, Leucanthemum vulgare, Plantago lanceolata, and Rumex acetosa (Van der Meijden 2005)). These species frequently co-occur in grassland on dike slopes in Western Europe (Schaminée and others 2010). The experiment included four diversity treatments $(1,2,4$, and 8 species). Each plot was randomly assigned to one of the four treatments. Within each diversity treatment, each species occurred in an equal number of plots, so that diversity effects could be measured independent of species effects. In the period May 2012-May 2013, we measured net annual soil loss through erosion in each of the plots.

The dike was built in February 2010 with a height of $67 \mathrm{~cm}$ and a length of $60 \mathrm{~m}$. On the south slope $\left(45^{\circ}\right)$, we laid out 98 plots measuring $60 \mathrm{~cm}$ (width) by $90 \mathrm{~cm}$ (upslope) (Figure 1). The dike body was composed of a soil mixture with organic matter content $17.1 \mathrm{mg} / \mathrm{g}, \mathrm{pH}\left(\mathrm{H}_{2} \mathrm{O}\right) 6.58$, total $\mathrm{N}$ content $25.7 \mathrm{mmol} / \mathrm{kg}$, and total $\mathrm{P}$ content 4.33 $\mathrm{mmol} / \mathrm{kg}$. The plots included 24 single-species plots ( 3 plots per species), all 282 -species combinations plots, 384 -species plots, and 88 -species plots. The species composition in 4-species plots was chosen by constrained random selection, in which selecting a given composition twice was not allowed and each species occurred in half of the plots. In the 


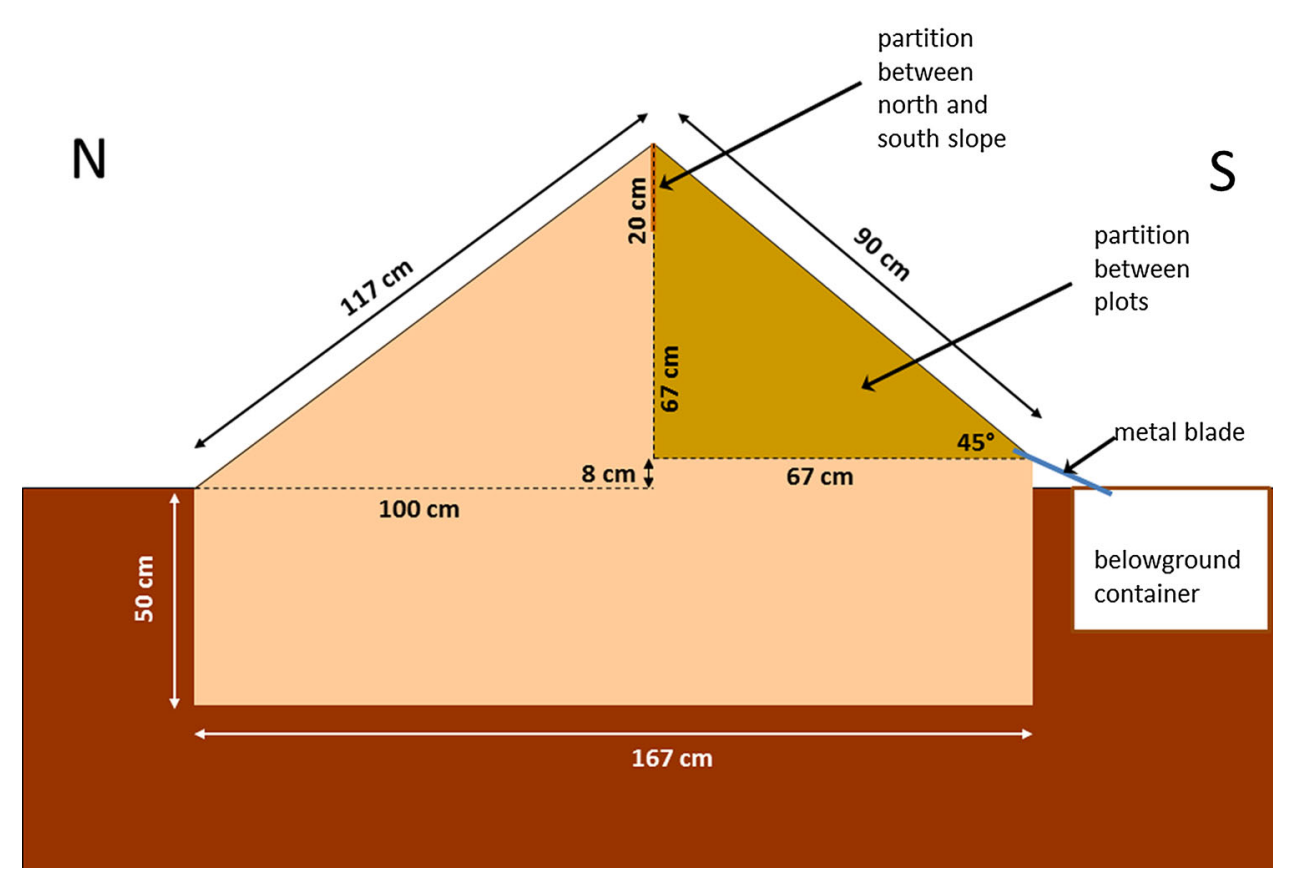

Figure 1. Cross section of the simulated dike, showing dimensions.

week 22-25 March 2010, seedlings (c. 4 weeks after germination) of each species were planted in an orthogonal pattern at a density of 148 seedlings $/ \mathrm{m}^{2}$.

Aboveground plant mass was measured by clipping the plants at a height of $1 \mathrm{~cm}$ simulating the annual mowing of the hayfields on dike slopes. The outer rows of plots were clipped, but not included in the biomass sample. Due to the high productivity in the first 2 years, plants were clipped twice in 2010 (July and September) and 2011 (June and September). In 2012, when productivity had declined, plants were harvested once (August).

From 10th May 2012 to 2nd May 2013, cumulative soil loss through erosion was measured in each plot, using a metal blade that was pressed gently into the soil along the total length of the base of the plot. During rainfall, eroded material flushed into a belowground receptacle that was emptied every 2 weeks. To prevent pollution of the collected material with aboveground litter, we determined the mineral content by weighing the samples before and after heating at $550^{\circ} \mathrm{C}$ for $3 \mathrm{~h}$. In September 2013, after completion of the erosion measurements, three root samples (diameter $7 \mathrm{~cm}$, depth $40 \mathrm{~cm}$ ) were taken in each monoculture and six samples in each 8 -species plot to measure root mass. Two small samples (diameter $1 \mathrm{~cm}$; depth $40 \mathrm{~cm}$ ) per plot were taken for root length measurements. After the erosion measurements, dead plants were replaced.
Amounts of eroded material in subsequent 2week periods were summed and log transformed. Effects of diversity were tested using log-linear regression. Moreover, we analyzed the effects of diversity using a General Linear Model, with measured erosion as dependent variable, diversity as fixed factor, and expected erosion (calculated on the basis of erosion measured in monocultures) as covariate. Pairwise differences between the slopes of the measured versus expected erosion relationships at the four diversity levels were tested by calculating least significant differences. Multicomparisons of erosion in single-species plots were performed using independent samples $t$ tests with Bonferroni correction. The effects of the presence of the different species on soil loss within the 2-and 4-species treatments were tested using an ANOVA, with species presence, diversity, and their interaction as fixed factors. Tests of differences within diversity levels were performed using independent samples $t$ test, after Levene's test for equality of variances and required corrections if variances differed significantly. The response of species $i$ to the extinction of Plantago in the 2- and 4-species plots was analyzed by calculating the ratio between the Relative Yields in 2012 and $2011\left(\log \left(\mathrm{RY}_{i, 2012}\right)\right.$ $\mathrm{RY}_{i, 2011}$ ) with $\mathrm{RY}_{i}=\mathrm{O}_{i} / \mathrm{M}_{i}, \mathrm{O}_{i}$ being the biomass of species $i$ in mixture and $\mathrm{M}_{i}$ the biomass of species $i$ in monoculture). Differences in response between plots where Plantago went extinct and plots where Plantago had not been planted were tested using 
independent samples $t$ tests, using required corrections if variances differed significantly. To test the effects of diversity on aboveground biomass in the three consecutive years, we applied a repeated measures analysis, with years as within-subjects factor and diversity as between-subjects factor. Net diversity, selection, and complementarity effects were calculated following the Loreau and Hector procedure (2001). The impacts of diversity on these components were analyzed using ANOVA. Calculations were performed using IBM SPSS Statistics version 20 .

\section{Results AND Discussion}

\section{Diversity and Species Effects on Soil Loss Through Erosion}

Loss of plant species diversity reduced soil erosion resistance $\left(F_{1,96}=6.58 ; P=0.012\right)$. Soil losses increased by $53 \pm 31 \%$ (mean \pm SE) when diversity declined from 4 to 2 species and by another

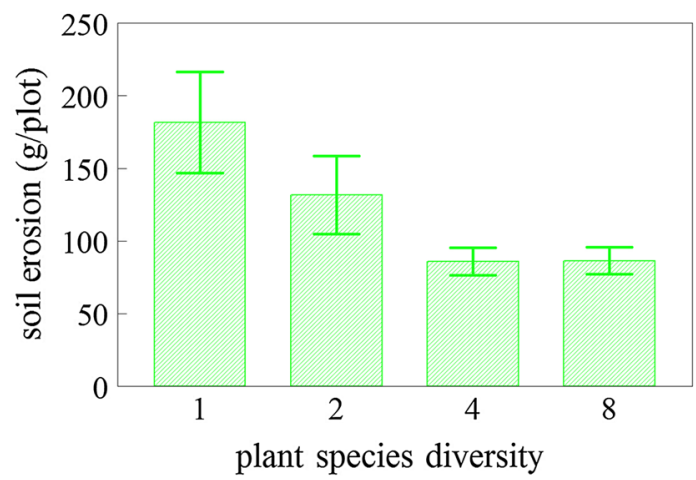

Figure 2. The effects of plant species diversity on soil loss through erosion. Annual soil loss was measured during 2-week periods between May 10th 2012 and May 2nd 2013 from plots 60 -cm wide and $90-\mathrm{cm}$ long. Mean \pm SE are given. Effects of diversity were tested using log-linear regression $\left(F_{1,96}=6.58 ; P=0.012\right)$.
$38 \pm 26 \%$ with a further decline from 2 to 1 species (Figure 2; Table 1). In the single-species stands, the different plant species had strongly diverging effects on soil erosion (Figure 3 ). The least loss of soil was measured in the plots planted with the grass Festuca, whereas soil losses from plots with only Plantago or Rumex were much greater. In the plots with these two species, part of the ground was left bare which explains the high erosion losses. There were also important differences between the six other species that all produced a dense vegetation cover. Erosion losses from the most productive monocultures (Centaurea) exceeded those from the much less productive Festuca plots by a factor five. Erosion in Festuca stands was also significantly less than in plots of Anthoxanthum or Leucanthemum.

To investigate the species effects in the multispecies plots, we compared plots with and without each of the species in the 2- and 4-species treatments (in the 8 -species treatment all species were present in each plot). This analysis revealed significant effects of the presence of the grasses Festuca and Agrostis and the dicot Plantago. Festuca and Agrostis reduced erosion $\left(F_{1,62}=9.4, \quad P=0.003\right.$; $F_{1,62}=11.2, P=0.001$, respectively) at both levels of diversity, (the interaction with diversity was not significant: $\quad F_{1,62}=0.04, \quad P=0.839 ; \quad F_{1,62}=2.3$, $P=0.135$, respectively). The presence of Plantago had opposite effects and increased soil loss $\left(F_{1,62}=15.1, P<0.001\right)$. An important event in the dynamics of the multi-species plots was the death of many Plantago plants in the winter of 2011/2012, a few months before the start of the erosion measurements. However, the effect of Plantago differed between the two diversity levels $\left(F_{1,62}=4.8, \quad P=0.032\right)$. The former presence of Plantago increased soil loss in the 2 -species plots $(t=3.43, \mathrm{df}=26, P=0.002)$, but not in the 4 species plots $(t=1.55, \mathrm{df}=36, P=0.131)$, illustrating the buffering capacity of the higher diversity level, as further discussed below.

Table 1. Pairwise Comparisons Between the Measured Erosion at Different Diversity Levels

\begin{tabular}{llcrr}
\hline Diversity & Diversity & Mean difference & SE & \multicolumn{1}{c}{ 0.004 } \\
\hline 1 & 2 & 0.430 & 0.144 & $<0.001$ \\
& 4 & 0.766 & 0.137 & $\mathbf{0 . 0 0 2}$ \\
& 8 & 0.685 & 0.213 & $\mathbf{0 . 0 1 1}$ \\
2 & 4 & 0.335 & 0.129 & 0.222 \\
4 & 8 & 0.255 & 0.207 & 0.689
\end{tabular}

$P$-values $<0.05$ are given in bold.

To control for the diverging species effects on erosion and the variation in species composition within diversity treatments, we calculated the expected erosion for each plot on the basis of the species proportions and the erosion measured in the single-species plots. A GLM with expected erosion as covariate revealed that diversity had significant impacts on erosion in addition to the effects of the different species (diversity: $F_{3,93}=85.7, P<0.001$; expected erosion: $F_{1,93}=10.9, P<0.001$ ). Pairwise differences between the effects of the covariate were tested by calculating least significant differences. 


\section{Compensating Mechanisms and Their Effects on Soil Erosion}

To further investigate this buffering capacity, we analyzed the response of the other species to the Plantago extinctions. We calculated relative yields $\left(\mathrm{RY}_{i}\right)$, which measure the species performance in mixture relative to that in monoculture $\left(\mathrm{RY}_{i}=\mathrm{O}_{i} /\right.$ $\mathrm{M}_{i}, \mathrm{O}_{i}$ being the biomass of species $i$ in mixture and $\mathrm{M}_{i}$ the biomass of species $i$ in monoculture). The

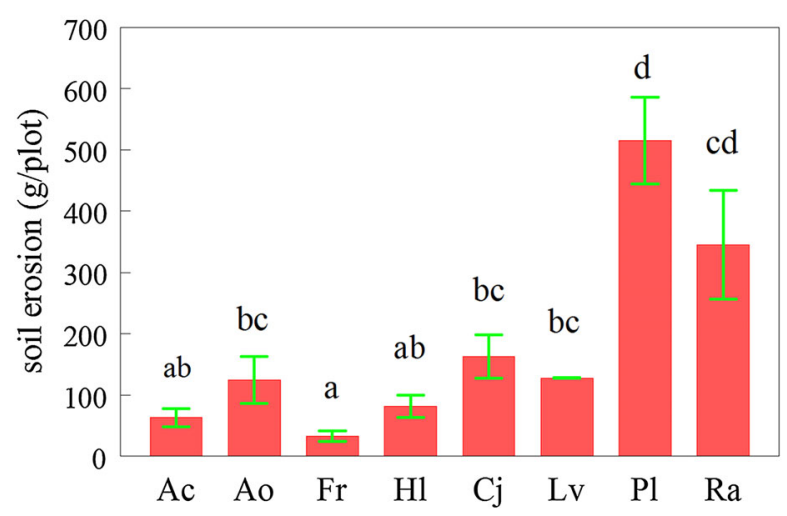

Figure 3. The effects of plant species in single-species stands on soil loss through erosion. Annual soil loss was measured during 2-week periods between May 10th 2012 and May 2nd 2013 from plots 60-cm wide and $90-\mathrm{cm}$ long. Mean $\pm \mathrm{SE}$ are given. Effects of species on erosion were tested using ANOVA $\left(F_{7,16}=16.34\right.$, $P<0.001)$. Multiple comparisons were performed using LSD tests with Bonferroni's correction. Ac, Agrostis capillaris; Ao, Anthoxanthum odoratum; Fr, Festuca rubra;; Hl, Holcus lanatus; Cj, Centaurea jacea; Lv, Leucanthemum vulgare; Pl, Plantago lanceolata; Ra, Rumex acetosa. response of species i to the extinction of Plantago in the 2- and 4-species plots was analyzed by calculating the ratio between the relative yields in 2012 and $2011\left(\log \left(\mathrm{RY}_{i, 2012} / \mathrm{RY}_{i, 2011}\right)\right)$. Between 2011 and 2012, relative yields of all species-except Holcus-increased in the plots where Plantago went extinct relative to the plots where Plantago was not planted and no extinctions occurred (Table 2). As a next step, we tested the effects of the presence of each species on soil erosion in the 2- and 4-species plots with and without Plantago. In plots where Plantago was present but disappeared, the presence of Festuca significantly reduced erosion relative to the erosion expected on the basis of the measured soil losses in the monocultures $(t=2.79, \mathrm{df}=16.9$, $P=0.013)$. This effect was not found in the plots where Plantago was not planted $(t=0.42, \mathrm{df}=7.3$, $P=0.69)$. The other species did not show any significant effect.

Apparently, the presence of Festuca reduced the increased erosion that resulted from the Plantago extinction wave, whereas the probability that this species was available increased with the increasing diversity. This important impact of Festuca provides a striking example of the compensation (Gonzalez and Loreau 2009) or insurance effect, which is the capacity of diverse communities to supply species that can rapidly take over the functions of species that have gone extinct as a consequence of fluctuating environmental conditions (Gonzalez and Loreau 2009; Tilman 1996; Doak and others 1998; Loreau and others 2001). This phenomenon buffers ecosystem functions analogously to the way diverse investment portfolios spread financial risks and thereby assure high-average long-term performance (Hector and Bagchi 2007).

Table 2. The Change in Relative Yield (RY) between 2011 and 2012 in +Plantago and -Plantago Plots

\begin{tabular}{|c|c|c|c|c|c|}
\hline & \multicolumn{2}{|c|}{$\log \left(\mathrm{RY}_{2012} / \mathrm{RY}_{2011}\right)$} & \multirow[t]{2}{*}{$t$} & \multirow[t]{2}{*}{$\mathrm{df}$} & \multirow[t]{2}{*}{$P$} \\
\hline & +Plantago & -Plantago & & & \\
\hline Agrostis capillaris & 1.159 & 0.232 & 3.15 & 24 & 0.004 \\
\hline Anthoxanthum odoratum & 0.878 & -0.099 & 4.74 & 24 & $<0.001$ \\
\hline Festuca rubra & 1.057 & 0.158 & 3.32 & 24 & 0.003 \\
\hline Holcus lanatus & 0.321 & -0.551 & 1.97 & 24 & 0.06 \\
\hline Centaurea jacea & 1.043 & 0.114 & 5.72 & 23 & $<0.001$ \\
\hline Leucanthemum vulgare & 0.984 & -0.645 & 4.34 & 24 & $<0.001$ \\
\hline Rumex acetosa & 2.818 & -0.106 & 4.05 & 22.8 & 0.001 \\
\hline
\end{tabular}



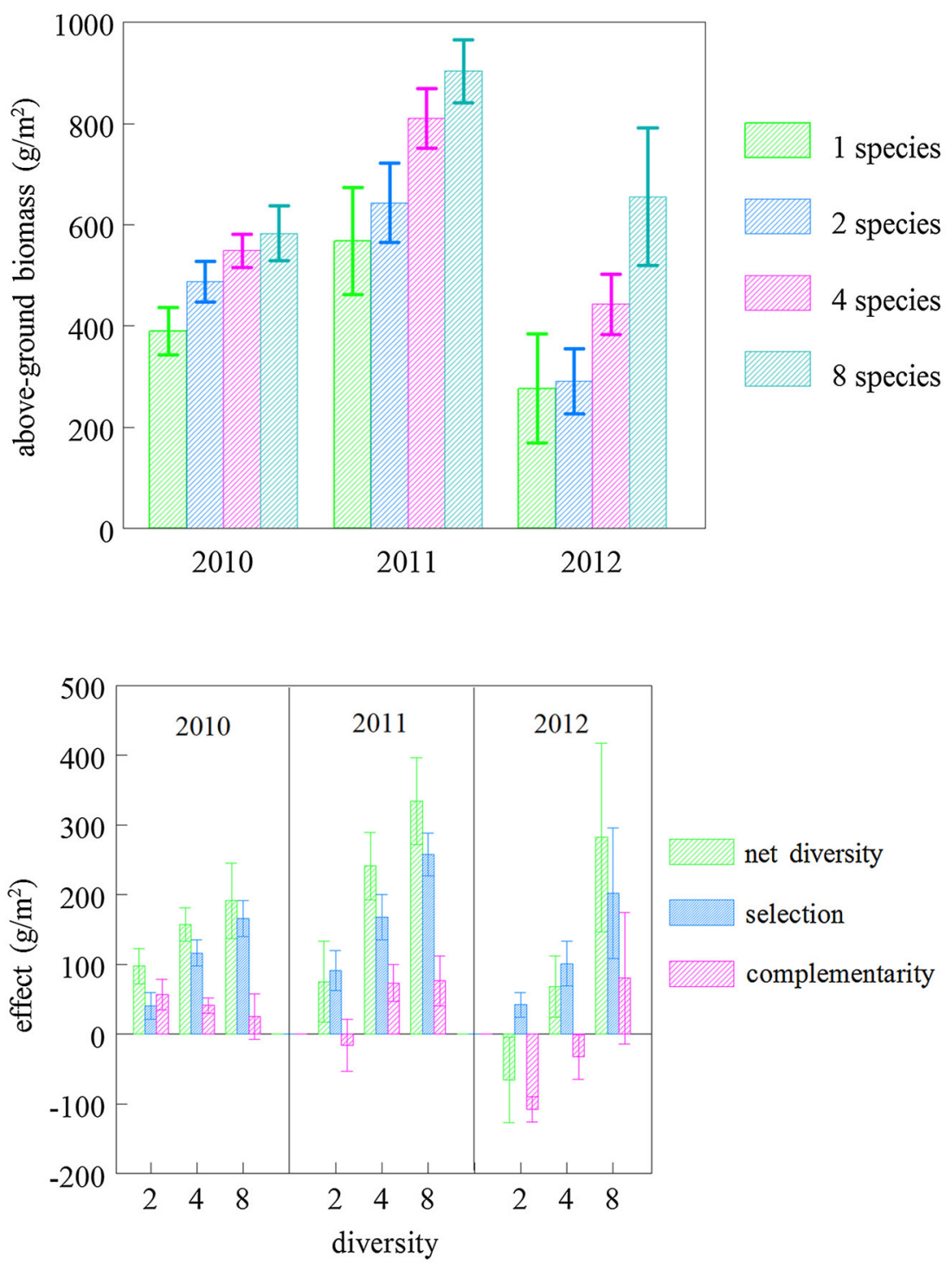

Figure 4. The effects of diversity on aboveground plant mass in 2010, 2011, and 2012. Mean \pm SE are given. The diversity effects were significant during the whole period (repeated measures:

$F_{3,94}=3.54, P=0.018$ ) and in each year (ANOVA: 2010, $F_{3,94}=5.06, P=0.003$; $2011, F_{3,94}=5.47$, $P=0.002 ; 2012$, $\left.F_{3,92}=7.78, P<0.001\right)$.
Figure 5. Net diversity, selection, and complementarity effects in the 2-, 4-, and 8species mixtures in three consecutive years. Mean \pm SE are given.

\section{Biomass Effects on Soil Erosion}

Earlier studies have consistently shown that in addition to aboveground biomass reducing splash erosion, root mass and root length have decisive impacts on the resistance to rill erosion (Gyssels and others 2005; Durán Zuazo and Rodríguez Pleguezuolo 2008). The question is whether diversity effects on plant biomass also contributed to reduced erosion losses. In monocultures, soil loss was negatively correlated to shoot mass, root mass, and root length (Pearson correlation coefficients: $-0.646, \quad P=0.001 ;-0.650, \quad P=0.001 ;-0.604$, $P=0.002$, respectively), although these variables were also strongly correlated with each other. In each of the years, aboveground biomass production increased with the increasing diversity (repeated measures: $F_{3,94}=3.54, P=0.018$; Figure 4 ). Similarly, root mass in the 8 -species plots was $71.3 \pm 28.8 \%$ (mean $\pm \mathrm{SE}$ ) greater than the root mass that was expected on the basis of the root mass in the monocultures $(t=2.47, \mathrm{df}=7, P=0.043)$, and the total root length was even $126.6 \pm 38.1 \%$ higher $(t=3.32, \mathrm{df}=7, P=0.013)$.

For shoot biomass, we could separate the diversity effects on biomass production into selection and complementarity effects (Loreau and Hector 2001) (Figure 5). In 2010 and 2011, the positive effect of diversity on biomass production was mainly explained by selection effects, that is, an increased probability of including a productive species (in this case Plantago) with more than proportional effects on total community productivity (Table 3). In 2012, the positive effects of diversity were jointly driven by selection effects (due to Centaurea) and by complementarity effects, that is, diverse stands utilizing the available resources 
Table 3. The Effects of Diversity on the Net Diversity, Selection, and Complementarity Effects (Using ANOVA)

\begin{tabular}{lrc}
\hline & $F_{1,72}$ & $P$ \\
\hline Net diversity effect & & \\
2010 & 3.32 & 0.073 \\
2011 & 6.08 & $\mathbf{0 . 0 1 6}$ \\
2012 & 8.73 & $\mathbf{0 . 0 0 4}$ \\
Selection effect & & \\
2010 & 10.72 & $\mathbf{0 . 0 0 2}$ \\
2011 & 6.34 & $\mathbf{0 . 0 1 4}$ \\
2012 & 5.52 & $\mathbf{0 . 0 2 2}$ \\
Complementarity effect & & \\
2010 & 0.85 & 0.360 \\
2011 & 2.67 & 0.106 \\
2012 & 4.52 & $\mathbf{0 . 0 3 7}$ \\
& & \\
\hline P-values <0.05 are given in bold. & & \\
\hline
\end{tabular}

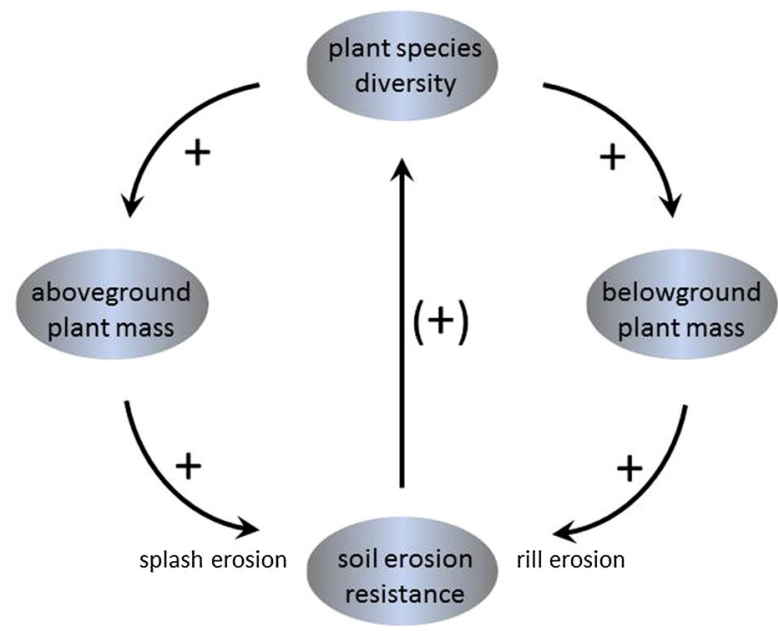

Figure 6. Effects of the restoration of plant species diversity on aboveground and belowground plant mass leading to reduced splash or rill erosion. In this paper, we show the positive effects of plant species diversity on soil erosion resistance. On very nutrient-poor substrates, increased erosion resistance might trigger positive feedback loops, which would accelerate the increase in species diversity and erosion resistance.

more completely than less diverse stands. But in that year, the average complementarity effect did not deviate significantly from zero. In addition, regression analysis did not reveal any significant relation between the complementarity effect per plot and measured annual soil loss, suggesting that niche complementarity did not contribute directly to reduced soil erosion.

\section{Conclusions}

Our findings show that loss of plant species diversity has important effects on the erosion resistance of slopes. In our experiment, these impacts were attributable to the loss of the insurance effect. Although it is likely that the measured positive effects of plant diversity on biomass production also contributed to increased erosion resistance, we did not provide unequivocal evidence for this causal relationship. Nevertheless, it is clear that the loss of species diversity can have profound, destabilizing effects on erosion resistance.

The reported experiment was carried out on a fertile soil, but on extremely nutrient-poor substrates (for example, in overgrazed pastures) loss of soil fertility due to increased erosion often leads to a further decline of plant species diversity (Grime 2001), which might trigger a feedback loop that accelerates the decline in species diversity and erosion resistance (Figure 6). We conclude that protection and restoration of diverse plant communities on slopes are essential to minimize soil erosion, which will not only contribute to greater safety in many estuarine areas around the world, but will also help maintain soil fertility on pasture land.

\section{ACKNOWLEDGMENTS}

We thank Jan van Walsem and Frans Möller who performed the soil loss and plant biomass measurements, and Martin Scheffer and Peter Klinkhamer for their helpful comments on an earlier version of the manuscript.

\section{OPEN ACCESS}

This article is distributed under the terms of the Creative Commons Attribution License which permits any use, distribution, and reproduction in any medium, provided the original author(s) and the source are credited.

\section{REFERENCES}

Berendse F, Oomes MJM, Altena HJ, Elberse WT. 1992. Experiments on the restoration of species-rich meadows in The Netherlands. Biol Conserv 62:59-65.

Cardinale BJ, Duff JE, Gonzalez A, Hooper DU, Perrings C, Venail P, Narwani A, Mace GM, Tilman D, Wardle DA, Kinzig AP, Daily GC, Loreau M, Grace JB, Larigauderie A, Srivastava DS, Naeem S. 2012. Biodiversity loss and its impact on humanity. Nature 486:59-67.

Cerdan O, Govers G, Le Bissonnai Y, Van Oost K, Poesen J, Saby N, Gobin A, Vacca A, Quinton J, Auerswald K, Klik A, Kwaad FPJM, Raclot D, Ionita I, Rejman J, Rousseva S, Muxart T, 
Roxo MJ, Dostal T. 2010. Rates and spatial variations of soil erosion in Europe: a study based on erosion plot data. Geomorphology 122:167-77.

Delta Commissie. 2008. Working together with water. A living land builds for its future. Findings of the Delta Commissie. The Hague, The Netherlands. www.deltacommissie.com/doc/ deltareport_full.pdf.

Dias AA, van Ruijven J, Berendse F. 2010. Plant species richness regulates soil respiration through changes in productivity. Oecologia 163:805-13.

Doak DF, Bigger D, Harding EK, Marvier EA, O'Malley RA, Thomson D. 1998. The statistical inevitability of stability-diversity relationships in community ecology. Am Nat 151:264-76.

Durán Zuazo VH, Rodríguez Pleguezuolo CR. 2008. Soil-erosion and runoff prevention by plant covers. A review. Agron Sust Dev 28:65-86.

Elberse WT, van der Bergh JP, Dirven JGP. 1983. Effects of use and mineral supply on the botanic composition and yield of old grassland on heavy clay soil. Neth J Agric Sci 31:62-88.

Gonzalez A, Loreau M. 2009. The causes and consequences of compensatory dynamics in ecological communities. Ann Rev Ecol Evol Syst 40:393-414.

Grime JP. 2001. Plant strategies, vegetation processes and ecosystem properties. 2nd edn. Chichester: Wiley.

Gross K, Cardinale BJ, Fox JW, Gonzalez A, Loreau M, Wayne Polley W, Reich PB, Van Ruijven J. 2014. Species richness and the temporal stability of biomass production: a new analysis of recent biodiversity experiments. Am Nat 183:1-12.

Gyssels G, Poesen J, Bochet E, Li Y. 2005. Impact of plant roots on the resistance of soils to erosion by water: a review. Prog Phys Geogr 29:189-217.

Handa IT, Aerts R, Berendse F, Berg MP, Bruder A, Butenschoen O, Chauvet E, Gessner MO, Jabiol J, Makkonen M, McKie BG, Malmqvist B, Peeters ETHM, Scheu S, Schmid B, Van Ruijven J, Vos VCA, Hättenschwiler S. 2014. Consequences of biodiversity loss for litter decomposition across biomes. Nature 509:218-21.

Hector A, Bagchi R. 2007. Biodiversity and ecosystem multifunctionality. Nature 448:188-91.

Hector A, Schmid B, Beierkuhnlein C, Caldeira MC, Diemer M, Dimitrakopoulos PG, Finn JA, Freitas H, Giller PS, Good J, Harris R, Högberg P, Huss-Danell K, Joshi J, Jumpponen A, Körner C, Leadley PW, Loreau M, Minns A, Mulder CPH, O'Donovan G, Otway SJ, Pereira JS, Prinz A, Read DJ, Scherer-Lorenzen M, Schulze E-D, Siamantziouras A-SD, Spehn EM, Terry AC, Troumbis AY, Woodward FI, Yachi S, Lawton JH. 1999. Plant diversity and productivity experiments in European grasslands. Science 286:1123-7.

Kateb HE, Zhang H, Zhang P, Mosandl R. 2013. Soil erosion and surface runoff on different vegetation covers and slope gradients: a field experiment in Southern Shaanxi Province, China. Catena 105:1-10.
Loreau M, Hector A. 2001. Partitioning selection and complementarity in biodiversity experiments. Nature 412:72-6.

Loreau M, Naeem S, Inchausti $P$, Bengtsson J, Grime JP, Hector A, Hooper DU, Huston MA, Raffaelli D, Schmid B, Tilman D, Wardle DA. 2001. Biodiversity and ecosystem functioning: current knowledge and future challenges. Science 294:804-8.

Mommer L, van Ruijven J, Berendse F, Ouborg NJ. 2010. Unveiling below-ground species abundance in a biodiversity experiment: a test of verical niche differentiation among grassland species. J Ecol 98:1117-27.

Netherlands Environmental Assessment Agency. 2010. Assessing an IPCC assessment. An analysis of statements on projected regional impacts in the report. The Hague/Bilthoven: Environmental Assessment Agency.

Parry ML, Canziani OF, Palutikof JP, van der Linden PJ, Hanson CE, Eds. 2007. Contribution of working group II to the fourth assessment report of the intergovernmental panel on climate change. Cambridge: Cambridge University Press.

Pierik M, van Ruijven J, Bezemer TM, Geerts RHME, Berendse F. 2011. Recovery of plant species richness during long-term fertilization of a species rich grassland. Ecology 92:1393-8

Pimentel D, Allen J, Beers A, Guinand L, Linder R, McLaughlin P, Meer B, Musonda D, Perdue D, Poisson S, Siebert S, Stoner K, Salazar R, Hawkins A. 1987. World agriculture and soil erosion. BioScience 37:277-83.

Ross DA. 1995. Introduction to oceanography. New York: Harper Collins College Publishers.

Schaminée J, Sykora K, Smits N, Horsthuis M. 2010. Plantengemeenschappen van Nederland. Zeist: KNNV Uitgeverij.

Silvertown J, Poulton P, Johnston E, Edwards G, Heard M, Biss PM. 2006. The park grass experiment 1856-2006: its contribution to ecology. J Ecol 94:801-14.

Tilman D. 1996. Biodiversity: population versus ecosystem stability. Ecology 77:350-63.

Tilman D, Reich PB, Knops J, Wedin D, Mielke T, Lehman C. 2001. Diversity and productivity in a long-term grassland experiment. Science 294:843-5.

van der Meijden R. 2005. Heukels' Flora van Nederland. 23rd edn. Groningen: Wolters-Noordhoff.

van Ruijven J, Berendse F. 2005. Diversity-productivity relationships: initial effects, long-term patterns, and underlying mechanisms. Proc Natl Acad Sci USA 102:695-700.

van Ruijven J, de Deyn GB, Berendse F. 2003. Diversity reduces invasibility in experimental plant communities the role of plant species. Ecol Lett 6:910-18.

van Vuuren DP, Sala OE, Pereira HM. 2006. The future of vascular plant diversity under four global scenarios. Ecol Soc $11: 25$ 